6

\title{
Land Reform by Leverage: Kasus Redistribusi Lahan di Jawa Timur ${ }^{1}$
}

\author{
Endriatmo Soetarto ${ }^{2}$, Martua Sihaloho ${ }^{3}$ dan Heru Purwandari ${ }^{4}$
}

\section{Ringkasan}

Permasalahan sumberdaya agraria tanah merupakan salah satu 'tema pokok' yang marak dalam diskusi dan kajian berbagai pihak di Indonesia. Demikian kasus dan kajian agraria yang umum dan menjadi fakta yang kontekstual dan aktual terjadi. Tulisan ini akan berusaha memaparkan bagaimana kasus redistribusi lahan dipandang sebagai salah satu alternatif pencapaian tujuan reforma agraria, lebih tepatnya land reform by leverage. Redistribusi lahan yang terjadi di Jawa Timur kini telah menunjukkan dampak atau manfaat dalam peningkatan kesejahteraan masyarakat khususnya penerima redistribusi lahan.

Katakunci: Tanah, land reform by leverage, redistribusi, dan kesejahteraan

\section{Pendahuluan}

Negara Indonesia dikenal sebagai negara agraris sekaligus negara maritim. Sebagai negara agraris, tanah merupakan sumberdaya yang 'terpenting' dalam pengelolaan dan pemanfaatan sumberdaya alam/agraria. Dengan demikian fakta tentang sumberdaya tersebut tidak jarang 'mewarnai' maraknya diskusi dan kajian berbagai pihak di Indonesia. sekaligus menjadi tema pokok kajian yang ada. Sebagai sumberdaya yang dipandang dominan maka sumberdaya ini mendapat 'porsi' yang relatif lebih tinggi dalam hal pemanfaatannya. Sumberdaya agraria lainnya adalah udara dan kekayaaan alami yang melekat padanya serta dimanfaatkan dalam berbagai kegiatan ekonomi di bidang pertanian, perikanan, kehutanan, pertambangan dan 'kedirgantaraan'. Keseluruhan sumberdaya ini sangat tergantung dari berbagai pihak yang memanfaatkannya.

Fakta menunjukkan bahwa pemanfaatan sumberdaya agraria-tanah merupakan permasalahan yang kompleks karena sumberdaya ini tidak jarang berfungsi

\footnotetext{
${ }^{1}$ Tulisan ini merupakan artikel atas hasil penelitian yang berjudul 'Pemanfaatan Sumber-Sumber Agraria Lokal dalam Mendukung Ekonomi Keluarga (Studi Kasus di Desa Mendiro, Kabupaten Ngawi Propinsi Jawa Timur). Disampaikan Dalam Seminar Nasional Hasil Penelitian Dasar Tahun 2003, Hotel Readtop, Jakarta 12-14 Juli 2004.

${ }^{2}$ Adalah Peneliti Pusat Kajian Agraria, LPPM-IPB

${ }^{3}$ Adalah Peneliti Pusat Kajian Agraria, LPPM-IPB

${ }^{4}$ Adalah Peneliti Pusat Kajian Agraria, LPPM-IPB
} 
sebagai 'ajang kerjasama, eksploitasi, perusakan lingkungan' dan sebagainya. Salah satu permasalahan yang mengikutinya adalah masalah konflik pertanahan yang biasanya diawali oleh masalah ketimpangan struktur pemilikan dan penguasaan tanah.

Melihat kembali kebelakang, masalah ketimpangan struktur pemilikan dan penguasaan sumber-sumber agraria ini sesungguhnya sudah lama terjadi, sejak jaman pemerintahan kolonial Belanda, Jepang, Demokrasi Terpimpin, zaman Orde Baru dan menyusul lebih parah pada waktu akhir-akhir ini. Di era reformasi tahun 1998, masalah tersebut belum juga mendapat perhatian serius dari pemerintah walaupun sejak pemerintah Orde Baru permasalahan ini telah sangat bergejolak. Berdasarkan TAP MPR No. IX Tahun 2001 tentang Pembaruan Agraria dan Pemanfaatan Sumberdaya Alam, kita sudah dapat menyaksikan keinginan pemerintah dalam menangani kasus permasalahan pertanahan. Namun hingga kini belum menunjukkan titik terang dalam hal implementasi pelaksanaan ketetapan tersebut.

Penjelasan tentang berbagai kasus pertanahan, dapat dilihat dari adanya penyebab mendasar yakni ketimpangan kepemilikan dan penguasaan sumbersumber agraria. Permasalahan ini kemudian dapat menjadi potensi konflik pertanahan antara masyarakat dengan perusahaan atau pemerintah. Pokok bahasan dalam tulisan ini akan dibatasi pada: (1) Bagaimana proses redistribusi tanah dapat dijelaskan sebagai suatu program land reform, lebih tepatnya land reform by leverage dan (2) Bagaimana dampak redistribusi lahan dapat meningkatkan kesejahteraan keluarga peserta land reform?

\section{Kerangka Pemikiran}

Kompleksitas masalah agraria dewasa ini dapat ditunjukkan melalui berbagai permasalahan baik menyangkut pemilikan, penguasaan, pemanfaatan dan lainlain. Fakta agraria yang marak dewasa ini adalah kasus 'gerakan rakyat lapar tanah' yang menuntut 'redistribusi tanah' ataupun 'land reform'. Kasus ini dapat dipahami berawal dari ketidak-akses-an masyarakat terhadap sumberdaya agraria yang ada dihadapan 'petani', sementara tuntutan kebutuhan 'sejengkal perut' petani dan keluarganya sangat mengharapkan sumberdaya agraria untuk memenuhi kebutuhan mereka. Dalam kondisi yang tidak akses tersebut petani terorganisir dalam suatu tuntutan meminta redistribusi lahan yang tidak jarang melakukannya dengan cara 'kekerasan'. Demikian halnya dengan 'pemerintah' dan swasta yang kemudiaan 'melakukan perlawanan dengan tindakan represi oleh kekuatan 'militer'.

Salah satu alas akar permasalahan agraria di atas adalah masalah ketimpangan struktur agraria yang akhirnya menjadi pemicu perebutan akses antar stakeholders. Dalam tulisan ini, gerakan massa atau petani yang menuntut redistribusi lahan merupakan respon masyarakat karena ketimpangan struktur agraria. Gerakan ini juga dapat dipahami sebagai suatu pengawasan sosial yang dilakukan oleh masyarakat terhadap pemerintah. 
Gerakan 'tuntutan' masyarakat dengan dalih tanah yang ada dihadapan mereka adalah tanah leluhur berakhir dengan program redistribusi lahan perkebunan pada tahun 1995 yang diwujudkan tahun 1999 dan 2000. Program ini bagaikan 'angin segar' bagi masyarakat setempat karena pada tahun 2003, kondisi kesejahteraan relatif lebih baik dibandingkan kondisi sebelumnya. Dalam konsep land reform, maka tuntutan redistribusi lahan yang dilakukan oleh masyarakat merupakan land reform by leverage (reforma agraria dari bawah). Berbeda dengan land reform by grace yang diberikan atas dasar kebaikan pemerintah (Wiradi, 2001). Land reform by leverage ini sesungguhnya muncul sebagai respon masyarakat terhadap pemerintah karena land reform by grace sebagai harapan 'ideal' masyarakat atas solusi permasalahan ketimpangan struktur agraria tidak terwujud.

Secara ringkas kerangka pemikiran tulisan ini dapat dilihat pada bagan berikut:

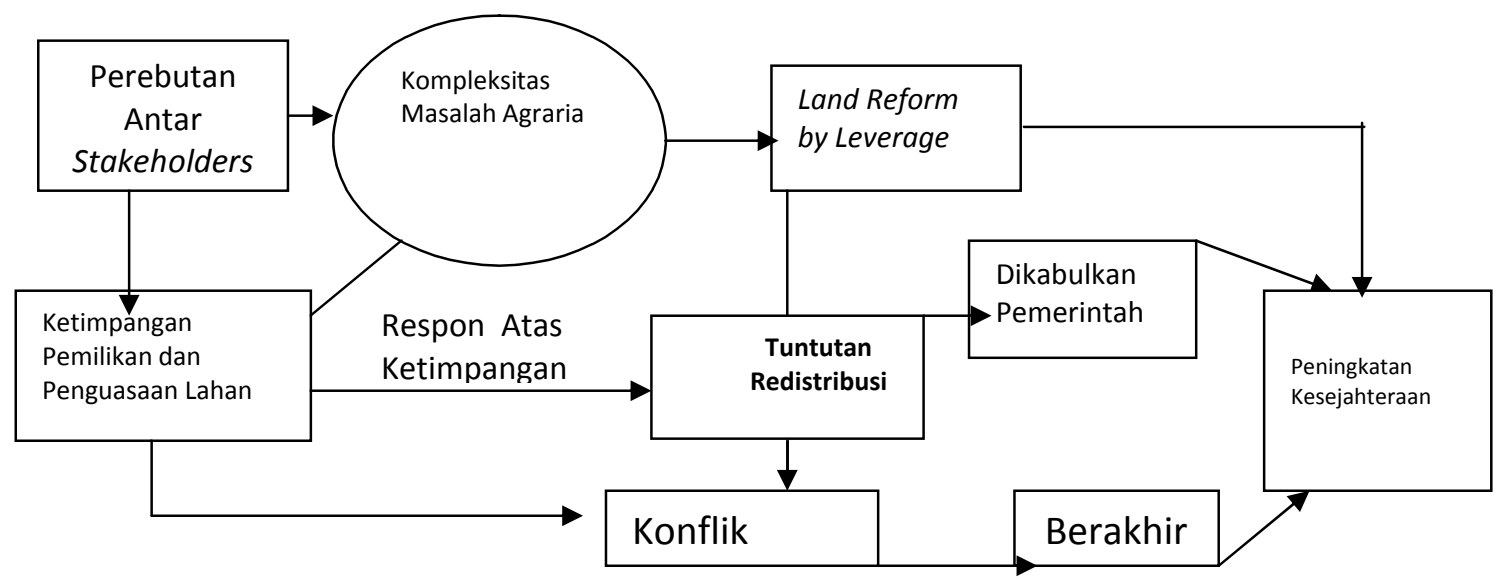

Bagan 1. Kerangka Pemikiran Redistribusi Lahan sebagai Land Reform By Leverage

\section{Masalah Agraria: Kasus Lokal Desa Mendiro, Kecamatan Ngrambe, Kabupaten Ngawi, Provinsi Jawa Timur}

Memahami masalah agraria lokal suatu masyarakat kita tidak lepas dari pemahaman struktur masyarakat lokal tersebut yang ditunjukkan dengan stratifikasi sosial atas dasar pemilikan lahan. Menurut Sitorus (2002) Lingkup agraria dapat dibedakan menjadi obyek agraria dan subyek agraria. Obyek agraria yang dimaksud adalah sumber-sumber agraria sebagaimana dijelaskan di atas. Subyek agraria adalah pemanfaat sumber-sumber agraria.

Pemanfaat sumber agraria tersebut dapat dibagi menjadi tiga yaitu komunitas (sebagai kesatuan dari unit-unit rumah tangga), pemerintah (sebagai representasi negara), dan swasta (private sector). Sebagai pemanfaat SSA, maka 
ketiga stakeholders tersebut memiliki ikatan dengan sumber-sumber agraria yang ada melalui institusi penguasaan/pemilikan (tenure institutions).

Lebih lanjut Sitorus membedakan hubungan antara subyek agraria dengan obyek agraria sebagai suatu hubungan teknis agraria. Sementara hubungan antar subyek agraria disebut sebagai hubungan sosio-agraria. Sebelum pada pembahasan struktur agraria di lokasi penelitian maka perlu dijelaskan juga struktur agraria di Jawa Timur. Dalam pelapisan sosial tradisional klasifikasi itu kemudian membedakan warga desa menjadi ${ }^{5}$ :

a. Kelompok warga desa inti (baku, gogol atau pribumi) sebagai keturunan para perintis dan pembuka desa. Kelompok ini memiliki tanah rumah dan hak serta kewajiban penuh sebagai warga desa dalam berbagai pekerjaan desa.

b. Indung, yaitu mereka yang memiliki sebidang tanah pertanian atau rumah. Indung memiliki hak dan kewajiban komunal terbatas.

c. Nusup, tlosor atau bujang. Kelompok ini tidak memiliki tanah atau pun rumah. Mereka bertempat tinggal di pekarangan orang lain, bekerja sebagai penyewa tanah atau petani kecil.

Golongan penduduk inti biasanya merupakan jumlah terbesar, tetapi karena pertambahan penduduk yang pesat jumlah kelompok ini dalam banyak kasus tidak melebihi $40 \%$ dari jumlah penduduk desa. Pada daerah-daerah yang hakhak komunalnya masih kuat, nusuo atau bujang memungkinkan mereka untuk naik kelas menjadi kelompok baku, kemudian diberi sebidang tanah untuk tanah oleh desa. Tetapi di daerah-daerah yang hak komunalnya lemah, penguasaan tanah perorangan dapat diperoleh terutama lewat jual beli atau warisan, dengan pengawasan masyarakat setempat.

Selanjutnya struktur agraria awal di Desa Mendiro yang dipahami dalam tulisan ini adalah struktur agraria sebelum proses redistribusi lahan atau (1995/1999). Struktur agraria tersebut dapat dipahami dari alokasi sumberdaya tanah yang dapat diakses oleh berbagai pihak. Seluas 551 ha lahan sawah dan 38 ha lahan kering dikuasai oleh perusahaan swasta ${ }^{6}$. Sementara masyarakat hanya menguasai seluas peruntukan permukiman masyarakat atau sekitar $17 \mathrm{Ha}$. Lebih jelasnya masyarakat dapat dikatakan tidak memiliki lahan atau tidak akses terhadap lahan sebagai suatu sumberdaya agraria yang dekat dengan masyarakat. Kondisi dimaksud terjadi di dua dusun di Desa Mendiro yaitu Dusun Sidomulyo dan Dusun Sarirejo.

Implikasi dari tidak aksesnya masyarakat (dua dusun) terhadap sumberdaya agraria tanah ditunjukkan dengan mata pencaharian utama masyarakat sebagai buruh perkebunan perkebunan di PD. Sumber Bakti yang pernah juga di HGU-kan kepada PT Naga Mas. Masyarakat hanya akses terhadap sumberdaya agraria akibat hubungan produksi atau hubungan ekonomi sebagai tenaga kerja di perkebunan. Hal yang menarik untuk dikaji adalah masyarakat diharuskan bekerja sebagai tenaga kerja di perusahaan tersebut. Sebagai unit ekonomi yang

\footnotetext{
${ }^{5}$ Aminuddin, K. Kaum Merah Menjarah.1999

${ }^{6}$ Termasuk wilayah Cepoko, Kecematan Ngrambe, Ngawi-Jawa Timur
} 
mengejar produksi dan keuntungan maka apabila masyarakat dua dusun tidak bekerja di perusahaan tersebut maka masyarakat akan mendapat sanksi dengan membayar denda kepada perusahaan.

\section{Konflik Sebagai Respon Ketimpangan Struktur Agraria 4.1. Identifikasi Konflik Pertanahan}

Di Desa Mendiro masyarakat memandang tanah yang di HGU-kan kepada Pemda setempat sebagai milik dan warisan para leluhur pembuka desa mereka yang pertama. Leluhur mereka ini dipercaya menjadi pemilik yang paling sah dan otentik atas lahan tersebut karena mereka yang pertama-tama membuka dan membangun serta mendiami kampung termasuk mengerjakan lahan-lahan pertanian baik lahan sawah maupun lahan kering. Asumsi dan anggapan inilah yang selanjutnya menjadi acuan masyarakat untuk menuntut hak milik atas tanah di Desa Mendiro.

Keinginan masyarakat tersebut tidak direspon oleh perusahaan, bahkan muncul pertentangan antara masyarakat dan perusahaan. Memang dalam kenyataannya di bawah penguasaan lahan oleh perusahaan ini, warga masyarakat lokal sebenarnya masih turut terlibat bekerja sebagai buruh tani pada tanah perkebunan. Akan tetapi, penghasilan yang diperoleh dari buruh tani dan pertanian belum dapat memenuhi kebutuhan hidup mereka. Kehidupan pada saat itu sangat sulit dirasakan oleh warga masyarakat khususnya yang menjadi buruh tani.

Dengan kata lain, warga hanya mampu bertahan hidup secara sangat sederhana dengan membuka usaha kecil atau terpaksa bermigrasi ke luar kota ${ }^{7}$. Kondisi sulit tersebut makin diperparah semenjak terjadi perubahan HGU dari PD. Sumber Bhakti kepada PT. Naga Mas, di mana pihak yang disebut terakhir ini ternyata justru menutup peluang warga masyarakat sekitar untuk terlibat bekerja sebagai buruh tani seperti pada waktu sebelumnya. Akibatnya sudah dapat diduga situasi ekonomi masyarakat makin sulit. Kenyataan yang mereka alami ini kemudian makin membakar semangat masyarakat untuk menuntut tanah warisan leluhur ${ }^{8}$ melalui aksi dan tuntutan redistribusi lahan.

Atas aksi yang dilakukan oleh pihak masyarakat, maka pihak perusahaan perkebunan harus mengalami kerugian'. Puncak dari aksi perjuangan masyarakat adalah menduduki tanah perkebunan dan tahun 1995 masyarakat telah mengusahakannya dengan menanam padi. Untuk menekan dan protes perlawanan petani, perusahaan tidak jarang menggunakan kekuatan militer

\footnotetext{
7 Biasanya yang melakukan migrasi ke kota adalah Laki-laki atau kepala rumah tangga. Namun demikian, penghasilan yang didapat belum mencukupi khususnya untuk biaya anak sekolah walapun hanya sampai pada tingkat SLTP.

8 Berdasarkan penuturan masyarakat kondisi yang dialami saat itu (PT. Naga Mas) merupakan suatu kondisi yang lebih parah jika dibandingkan dengan pada masa penjajahan. Dengan demikian mereka merasa tidak dapat bertahan terus dengan penderitaan yang dirasakannya.

9 Bidang usaha perkebunan di Desa Cepoko dan Mendiro merupakan basis dan andalan PD. Sumber Bhakti (Wawancara dengan staf PD. Sumber Bakthi yang hingga kini masih tetap eksis. Namun lebih terpokus pada bidang kerja koperasi.
} 
untuk menghadapi rakyat, dan kekuatan birokrasi untuk mempersulit layanan sosial kepada rakyat yang tidak patuh, atau menekan dengan stigmatisasi untuk memberikan citra negatif terhadap rakyat yang melawan kebijaksanaan agraria pemerintah. Masyarakat yang melakukan perlawanan di cap sebagai antek dari PKI atau cap-cap lainnya yang intinya bermakna negatif yang menentang masyarakat sebagai pemicu timbulnya konflik.

\subsection{Penyelesaian Konflik}

Konflik atas kasus sengketa pertanahan yang terjadi pada dasarnya adalah antara masyarakat dengan PD. Sumber Bhakti dan PT. Naga Mas. Namun dalam proses penyelesaiannya ada dua pihak besar yang saling berhadapan, yaitu pihak yang mendukung masyarakat/menentang perusahaan dan pihak yang mendukung perusahaan/menentang masyarakat. Berikut hasil identifikasi terhadap dua pihak yang dimaksud.

Pihak yang mendukung masyarakat adalah kelompok yang mendukung tuntutan dan aspirasi masyarakat. Tuntutan dan aspirasi tersebut adalah:

a. Masyarakat dari enam kampung, dua desa di kecamatan Ngrambe, kabupaten Ngawi menuntut kembali lahan yang telah di HGU-kan kepada PD. Sumber Bhakti yang kemudian di HGU-kan lagi kepada pihak swasta yaitu PT. Naga Mas untuk menjadi hak kelola masyarakat dan menjadi hak milik. Tuntutan tersebut berdasarkan anggapan bahwa hak tanah mereka tersebut merupakan warisan dari para leluhur pendiri desa/kampung mereka terdahulu.

b. Masyarakat tidak mengharapkan adanya kompromi atau negosiasi yang bermaksud menjembatani kepentingan kedua belah pihak. Mereka hanya punya satu tuntutan yaitu tanah perkebunan harus kembali menjadi hak milik mereka. Tuntutan ini terlebih mereka lakukan karena didorong oleh 'urusan perut' yang tak dapat ditunda-tunda lagi.

c. Selanjutnya masyarakat menuntut apabila tanah diserahkan pada mereka maka pemerintah segera perlu mensertifikasi kepemilikannya agar memiliki ketetapan kekuatan hukum, dan untuk itu mereka sanggup membiayai urusan penyelesaian administratifnya.

Prinsip-prinsip perjuangan masyarakat adalah adanya anggapan bahwa tanah tersebut merupakan tanah warisan para leluhur pendiri desa. Mereka meminta lahan tersebut kepada pemerintah atau perusahaan. Satu hal yang paling mendasari perjuangan mereka adalah tanah yang diminta adalah untuk urusan perutnya, artinya untuk kebutuhan pokok agar masyarakat dapat survive atau bertahan hidup, bukan untuk memperkaya masyarakat yang yang sudah 'berada' atau kaya. Untuk itu, sebenarnya tidak ada alasan pemda untuk tidak mengabulkan permohonan masyarakat. Karena dalam pemahaman masyarakat pemda sangat tidak ingin masyarakatnya hidup dalam penderitaan dan kesengsaraan. 
Atas dasar itu motto perjuangan masyarakat adalah: kebersamaan, bersatu, kompak, berani dan pantang menyerah. Satu penekanan kata 'pokoknya' harus mendapat tanah, tidak boleh tidak. Dalam hal ini, motto khusus dari Pak Karno ${ }^{10}$ adalah sekarang mati, besok pun mati. Semangat dan tekad Pak karno ini pun kemudian menular luas pada rekan-rekan seperjuangannya.

Dalam pelaksanaan perjuangannya, komunikasi yang dilakukan adalah komunikasi primer, langsung atau dari mulut ke mulut. Sistem komunikasi ini dapat lebih cepat membakar semangat warga masyarakat untuk meneruskan tuntutannya. Jaringan kebersamaan antar warga langsung terbina berkat pimpinan pak Karno. Mereka sangat menginginkan agar pemda segera dapat mewujudkan program redistribusi tanah kepada masyarakat setempat dan mengalihkannya sekaligus menjadi hak milik baru masyarakat. Keinginan bersama ini juga dapat menumbuhkan rasa persatuan dan kesatuan masyarakat dan menjadi modal yang utama dalam suatu perjuangan.

Dalam menyampaikan tuntutannya, masyarakat tidak berjuang sendiri. Sejumlah anggota DPR/MPR pusat dari fraksi PPP, Golkar dan ABRI pun menyatakan dukungannya kepada warga masyarakat sekitar. Mereka menyatakan keprihatinannya terhadap situasi sulit yang dihadapi masyarakat, khususnya bagi mereka yang tidak memiliki lahan. Lahan tersedia di daerahnya sekitarnya, akan tetapi mereka menderita karena tanah tersebut di HGU-kan pada pihak luar. Atas dasar itu para anggota perwakilan rakyat tersebut merasa terpanggil untuk berperan memperjuangkan hak-hak petani atas lahan tersebut.

Dukungan lain juga datang dari Lembaga Bantuan Hukum-Solo ${ }^{11}$, dan dari para mahasiswa berbagai daerah yang khusus melakukan demonstrasi besar pada tanggal 10 November 2001 di kabupaten Ngawi ${ }^{12}$. Dukungan penting yang patut dicatat datang dari Komnas HAM.

Menyoroti aktivitas apa saja yang dijalankan masyarakat untuk menguatkan tuntutan mereka, dapatlah diidentifikasikan sebagai berikut: mereka melakukan gerakan-gerakan aksi demonstrasi menuntut tanah hak milik, turut aktif mengumpulkan kebutuhan dana swadaya masyarakat untuk berbagai keperluan termasuk untuk membiayai perjalanan wakil-wakil masyarakat (Pak Karno dan kawan-kawan) ke Jakarta yang mencapai kurang lebih 40 (empat puluh) kali kunjungan, menggelar pertemuan-pertemuan untuk melakukan konsolidasi lebih mantap atas aksi-aksi mereka, misalnya dalam rangka menyiapkan aksi pendudukan lahan tanaman perkebunan PD. Sumber Bhakti.

${ }^{10}$ Pak Karno merupakan pelopor masyarakat yang banyak memberikan perhatian penuh dalam tuntutan redistribusi tanah. Beliau lebih mendahulukan kepentingan tuntutan terhadap tanah dibandingkan kepentingan keluarganya. Beliau telah melakukan kunjungan ke Jakarta, Solo dan Surabaya dalam frekuensi yang cukup banyak (sekitar 40 kali). Hingga kini tokoh ini menjadi tseorang yang cukup dikenal dengan masalah tanah dan menjadi koordinator Desa Cepoko dalam mengurus pelunasan PBB khususnya Desa Mendiro.

${ }^{11}$ Masyarakat tidak mengingat nama LBH-Solo yang membantu/mendukung tuntutan mereka.

${ }^{12}$ Merupakan demonstrasi pertama dan terbesar di Kabupaten Ngawi yang menuntut redistribusi tanah. Jumlah peserta adalah sekitar 1000 orang yang terdiri dari warga masyarakat (petani), mahasiswa dan masyarakat luas yang turut menyaksikannya. 
Hal yang patut dicatat adalah bagaimana mereka berusaha untuk mewaspadai kemungkinan terjadinya tindak penyuapan yang sering dijumpai dalam aksiaksi serupa itu misalnya dengan cara pemberian 'iming-iming' oleh pihakpihak tertentu yang pro status quo.

Sebagaimana telah disebutkan di atas kepentingan masyarakat atas pengalihan lahan sebenarnya masih dalam batas-batas luasan yang minimal saja, yaitu sekitar 0.1-0.2 ha per individu/rumahtangga. Luasan lahan ini sesungguhnya hanyalah cukup untuk mendukung kebutuhan ekonomi rumahtangga dalam taraf sederhana saja.

Namun layaknya sebuah perjuangan maka biasanya sangat sulit mengindetifikasikan secara dini adanya 'musuh dalam selimut'. Di antara kelompok-kelompok masyarakat yang melakukan perjuangan ada saja yang terlibat dalam perpecahan pendapat atau kepentingan. Di antara mereka inilah yang kemudian potensial berubah menjadi lawan perjuangan, karena mudah ditunggangi atau disusupi kepentingan lain yang tak sejalan dengan perjuangan awal. Patut dikemukakan adanya sekelompok warga masyarakat yang tiba-tiba menjadi 'pahlawan kesiangan' padahal semula mereka tidak pernah terlibat aktif dalam perjuangan menuntut hak tanah menjadi milik masyarakat. Baru belakangan mereka terlihat terlibat dalam perjuangan padahal sebenarnya mereka hanya menginginkan mendapatkan jatah tanah.

Sementara itu, pihak-pihak yang menentang masyarakat dalam sisi lain berarti mendukung perusahaan. Seluruh pihak pada dasarnya mengambil inisiatif untuk terlibat karena dorongan berbagai kepentingan yang bervariasi di dalamnya. Namun secara umum sejumlah pihak-pihak yang mendukung perusahaan adalah Pemda Kabupaten Ngawi (Bupati, Camat, Kades), Kantor Sospol Kabupaten Ngawi, BPN Kabupaten Ngawi, Kodim, Korem Ngawi, pihak aparat desa Cepoko, desa Mendiro, serta sejumlah warga masyarakat asal 7 kampung pada desa yang bersangkutan ${ }^{13}$.

Seluruh pihak yang dimaksud di atas mempunyai kepentingan yang sama yaitu tetap menginginkan keberadaan perusahaan. Pihak- pihak ini senantiasa berupaya mengintensifkan konflik agar proses tuntutan masyarakat berlangsung lama dan diharapkan akan makin mereda karena melelahkan diri warga itu sendiri. Salah satu upaya yang menarik dicatat adalah pihak-pihak tersebut mencari jalan kompromi dengan mengumbar berbagai janji 'manis' atau 'iming-iming' misalnya dengan akan memberikan sesuatu yang berharga dengan syarat agar warga tidak meneruskan tuntutan redistribusi lahan ${ }^{14}$.

\footnotetext{
13 Masyarakat dari tujuh kampung tersebut tidak turut mendukung karena wilayah perkebunan yang disengketakan tidak termasuk pada wilayah mereka.

${ }^{14}$ Khususnya bagi pelopor, Saudara Karno.
} 


\subsection{Redistribusi Lahan: Salah Satu Proses Penyelesaian Konflik}

Proses penyelesaian masalah ini telah dilakukan sejak tahun 1954, secara bilateral antara pihak Pemda dan masyarakat. Pihak Pemda dalam hal ini selalu menawarkan pilhan atau alternatif penyelesaian masalah yang intinya membolehkan warga masyarakat untuk mengelola lahan perkebunan, namun dengan status hak garap atau bekerja sebagai buruh perkebunan, dan sebagainya. Namun pihak masyarakat tetap bersikukuh yaitu tetap pada pendiriannya yang menginginkan lahan dengan status hak milik. Namun karena upaya-upaya penyelesaian secara bilateral berhasil mencari jalan ke luar, maka pada pada tahun 1992 warga masyarakat mengambil prakarsa untuk mencari pihak lain (LBH Solo) sebagai fasilitator untuk membantu proses menengahi konflik tersebut. Upaya ini dalam perkembangannya sangat membantu pemberdayaan masyarakat karena mereka diberikan pengetahuan tentang proses-proses apa yang seharusnya mereka tempuh untuk mendapatkan haknya kembali secara legal.

Mengacu pada kasus di Kecamatan Ngrambe, masyarakat yang melakukan aksi demonstrasi bahkan mendapat cap sebagai anggota Partai Komunis Indonesia (PKI) sehingga sangat menyudutkan posisi mereka. Pendekatan represif sangat diandalkan pihak Pemda dan perkebunan, karena kebetulan dalam latar belakang sejarahnya daerah setempat ditengarai sebagai salah satu basis penting PKI di masa lalu ${ }^{15}$. Dengan menciptakan cap seperti ini, pemerintah seolaholah memiliki justifikasi untuk tidak menggubris protes petani tersebut. Berkaitan dengan hal di atas, kehidupan manusia yang bersifat dinamis mempunyai keinginan dan kebutuhan yang tidak terbatas sehingga akan mempunyai kebutuhan yang tinggi juga terhadap penguasaan sumber-sumber agraria terutama yang mereka anggap sebagai 'milik atau hak' mereka yang selama ini dirampas oleh pihak perusahaan.

Memasuki kurun waktu 1994 dukungan kuat datang dari Komnas HAM Pusat sejalan dengan makin kencangnya tuntutan masyarakat. Imbauan Komnas HAM yang dituangkan dalam sepucuk surat yang ditujukan kepada bupati dan kepada berbagai pihak di daerah yang meminta agar mereka lebih memperhatikan tuntutan masyarakat ternyata dapat meredakan sikap ngotot pihak perusahaan/Pemda selama ini.

Pada akhirnya proses penyelesaian kasus agraria tersebut di atas mengabulkan keinginan masyarakat. Artinya tuntutan masyarakat agar mereka mendapatkan hak tanah pada lahan perkebunan dipenuhi bahkan lengkap dengan proses sertifikasinya. Namun di sisi lain pihak perusahaan tetap mendapatkan haknya untuk terus beroperasi di daerah setempat. Namun dalam perkembangan lebih lanjut seluruh lahan perkebunan akhirnya di redistribusikan kepada warga masyarakat karena pihak Pemda rupanya mengambil sikap baru yang lebih

15 Pendekatan keamanan ini tidak sepenuhnya berhasil meredamkan konflik.Namun setidak-tidaknya cara ini dapat menjadi sarana yang efektif untuk meredam berbagai kasus pertanahan di berbagai tempat, sehingga tidak menimbulkan konflik terbuka yang cenderung dapat menyebabkan perpecahan. 
responsif terhadap seluruh aspirasi dan tuntutan yang dilancarkan warga masyarakat.

Tentu saja seluruh keberhasilan upaya tersebut ini tidaklah sederhana karena selain masyarakat harus tersita waktunya secara relatif panjang juga mereka lewat para tokoh-tokohnya harus melakukan ulet dan tekun melakukan berbagai lobby dan pendekatan secara bertingkat-tingkat melalui berbagai pertemuan-pertemuan di tingkat Kabupaten, Propinsi, maupun di tingkat pusat.

Sekilas proses penyelesaian tersebut hanya menguntungkan sepihak saja yaitu untuk masyarakat dan merugikan pihak perkebunan. Namun sesungguhnya dengan proses ini maka keadilan dan kemerataan kesejahteraan lebih mendapatkan tempatnya. Selanjutnya warga yang telah memiliki sertifikat tanah pun akan terus memberikan masukan dana pada Pemda melalui pembayaran PBB.

Inilah antara lain yang mendorong pihak Pemda untuk akhirnya menyetujui keinginan masyarakat berdasarkan satu pertimbangan bahwa pada dasarnya masyarakat sangat membutuhkan lahan untuk menyokong kehidupan ekonomi masyarakat dan ini akan menciptakan stabilitas sosial yang lebih berakar. Demikian konflik ini berakhir dengan program redistribusi lahan kepada masyarakat setempat (dua kampung).

\section{Redistribusi Lahan: Land Reform By Leverage ?}

Sebagaimana dijelaskan pada sub-bab sebelumnya, bahwa program redistribusi lahan mengakhiri konflik agraria yang terjadi di Desa Mendiro. Pada bab ini akan dijelaskan bahwa program redistribusi lahan ini sesungguhnya merupakan program yang mampu meningkatkan kesejahteraan masyarakat setempat. Pertanyaan selanjutnya adalah bagaimana program ini bisa meningkatkan kesejahteraannya. Jawaban atas pertanyaan tersebut akan dijelaskan dalam konteks perubahan kesejahteraan masyarakat sebelum dan sesudah redistribusi lahan.

Secara ringkas menurut pengakuan Pak Karno yang merupakan pelopor pergerakan masyarakat dalam tuntutan redistribusi lahan, jika dibandingkan dengan kondisi 4 tahun lalu khususnya setelah pembagian lahan secara resmi dilakukan maka perubahan tingkat kesejahteraan masyarakat dua kampung di Desa Mendiro ini telah mengalami peningkatakan 3-5 kali lipat. Salah satu penyebab utama peningkatan kesejahteraan ini adalah akses masyarakat setempat terhadap sumberdaya agraria tanah, walaupun hanya memiliki lahan seluas 0,2 ha. Namun karena lahan yang ada termasuk produktif untuk lahan pertanian dan juga untuk tanaman buah Melon, maka cerita lama dan kisah masa-masa sulit pada saat masyarakat bekerja di perkebunan dapat ditinggalkan jauh. 'Kini kami sudah sejahtera dan telah maju 3-5 langkah', demikian tutur Pak karno. 
Berikut akan kami jelaskan secara lebih rinci bagaimana signifikansi program redistribusi lahan terhadap peningkatan kesejahteraan masyarakat dalam berbagai aspek kehidupan masyarakat. Redistribusi yang diupayakan oleh masyarakat setempat memberi dampak yang cukup signifikan terhadap perubahan kondisi kesejahteraan ke taraf yang jauh lebih baik. Perubahan tersebut diakui oleh seluruh masyarakat dan dapat ditinjau dari berbagai sudut diantaranya adalah perbaikan terhadap kepemilikan/kebendaan (pemilikan lahan sawah, penampakkan rumah berserta segala isinya) dan perbaikan terhadap non materiil (rasa aman, pendidikan, orientasi terhadap masa depan, dan kehidupan sosial yang lebih baik).

Perbaikan materi yang tampak jelas adalah struktur bangunan rumah yang mulai permanen. Perbaikan-perbaikan rumah dilakukan setahap demi setahap sesuai dengan hasil panen padi. Perbaikan dari sisi non-materiil terutama dilihat dari tingkat pendidikan yang sudah dikecap oleh pemuda di kedua dusun tersebut. Jika pada saat sebelum redistribusi tamatan sekolah baru mencapai SMP saja, namun perbaikan kondisi ekonomi membawa pengaruh terhadap tingkat pendidikan dimana banyak yang sudah lulus SMU. Namun ada perbedaan antara dusun Sidomulyo dengan Sarirejo dalam hal tingkat pendidikan yang dicapai. Untuk Sarirejo banyak yang sudah menyekolahkan anaknya sampi ke perguruan tinggi bahkan ada 10 orang yang menadi ABRI. Sedangkan Sidomulyo agak sedikit ketinggalam karena satupun pemudanya tidak ada yang mengenyam bangku perguruan tinggi.

\section{Kesimpulan}

Beberapa benang merah sekaligus kesimpulan yang dapat disampaikan dalam tulisan ini adalah:

1. Masalah agraria merupakan masalah yang kompleks dan salah satu penyebab permasalahan tersebut adalah ketimpangan struktur agraria karena perbedaan akses terhadap sumberdaya agraria tersebut.

2. Konflik merupakan respon atas ketimpangan struktur agraria. Konflik juga dapat diakhiri dengan berbagai bentuk penyelesaiannya semisal redistribusi lahan.

3. Redistribusi lahan merupakan alternatif land reform by leverage sebagai respon atas harapan 'ideal' masyarakat yang belum diwujudkan oleh pemerintah yang dikenal dengan land reform by grace.

4. Kasus redistribusi lahan di dua dusun Desa Mendiro, Kecamatan Ngrambe, Kabupaten Ngawi, Provinsi Jawa Timur menunjukkan peningkatan kesejahteran dalam berbagai aspek dalam kurun waktu 4 tahun yang lalu.

5. Sebagai perwujudan land reform by leverage, kasus redistribusi di Desa Mendiro merupakan tuntutan atas ketidakaksesan masyarakat terhadap sumberdaya agraria tanah. Dan fakta menunjukkan bahwa pada saat masyarakat setempat akses terhadap sumberdaya agraria tanah walaupun hanya 0,2 ha sangat berarti dan mengisi 'relung aktivitas masyarakat lokal sebagai petani'. 


\section{Daftar Pustaka}

Husain, 1997. Konflik Pertanahan. Pustaka Sinar Harapan. Jakarta.

PKA, LP-IPB. 2000. Prosiding Seminar dan Lokakarya 'Metodologi Penelitian Agraria'. Tidak Diterbitkan Bogor.

PKA, LP-IPB. 2001. Laporan Akhir Studi Identifikasi Penyelesaian Kasuskasus Pertanahan/Agraria Melalui Pemberdayaan Masyarakat dan Pendekatan Negosiasi Antar Stakeholders di Daerah. Tidak Diterbitkan. Bogor.

Kasdi, A. 2001. Kaum Merah Menjarah : Aksi Sepihak PKI/BTI di fawa Timur 1960-1965. Penerbit Jendela. Yogyakarta.

Sitorus, MT.F. 2002. Lingkup Agraria dalam Suhendar et. al. 2002. Menuju Keadilan Agraria: 70 Tahun Gunawan Wiradi. Akatiga. Bandung

Wiradi, G. 2000. Reforma Agraria: Perjalanan Yang Belum Berakhir. Insist Press. Yogyakarta. 